\title{
Religion on Campus
}

\section{CONRAD CHERRY, BETTY A. DEBERG, AND AMANDA PORTERFIELD}

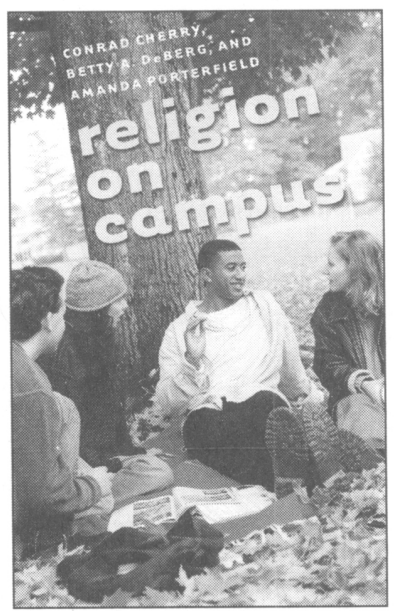
The first comprehensive study of the practice and teaching of religion at contemporary U.S. colleges and universities.

\section{"D} rovides striking first-hand information that calls into question the gloomy analyses presented in recent books about the secularization of American higher education. Through careful ethnographic case studies, the authors show us that contemporary students are interested in spirituality and for the most part seem to be finding ways of expressing this interest through coursework and other campus activities. yet the apparent superficiality of these students' religious understanding is also a lesson that educators will need to ponder seriously." -Robert Wuthnow, author of Creative Spirituality

Approx. 352 pp. $\$ 24.95$ cloth

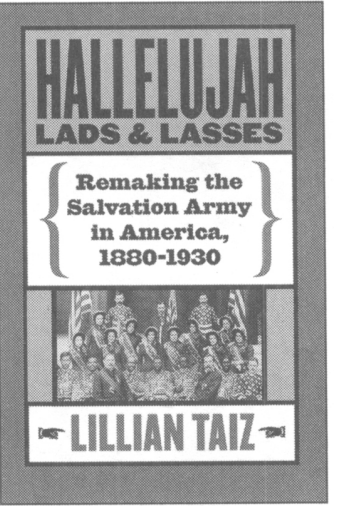

\section{Hallelujah Lads \& Lasses}

Remaking the Salvation Army in America, 1880-1930

\section{LILLIAN TAIZ}

"Probes the background and membership of the Salvation Army in America more thoroughly and with more sophistication than any previous study. ... [Taiz] explains how and why Americans who joined the Army subtly and directly transformed it. An engrossing book on a fascinating encounter between America's working classes and imported British evangelicalism." -Jon Butler, Yale University Approx. 272 pp. $\$ 39.95$ cloth / $\$ 16.95$ paper 


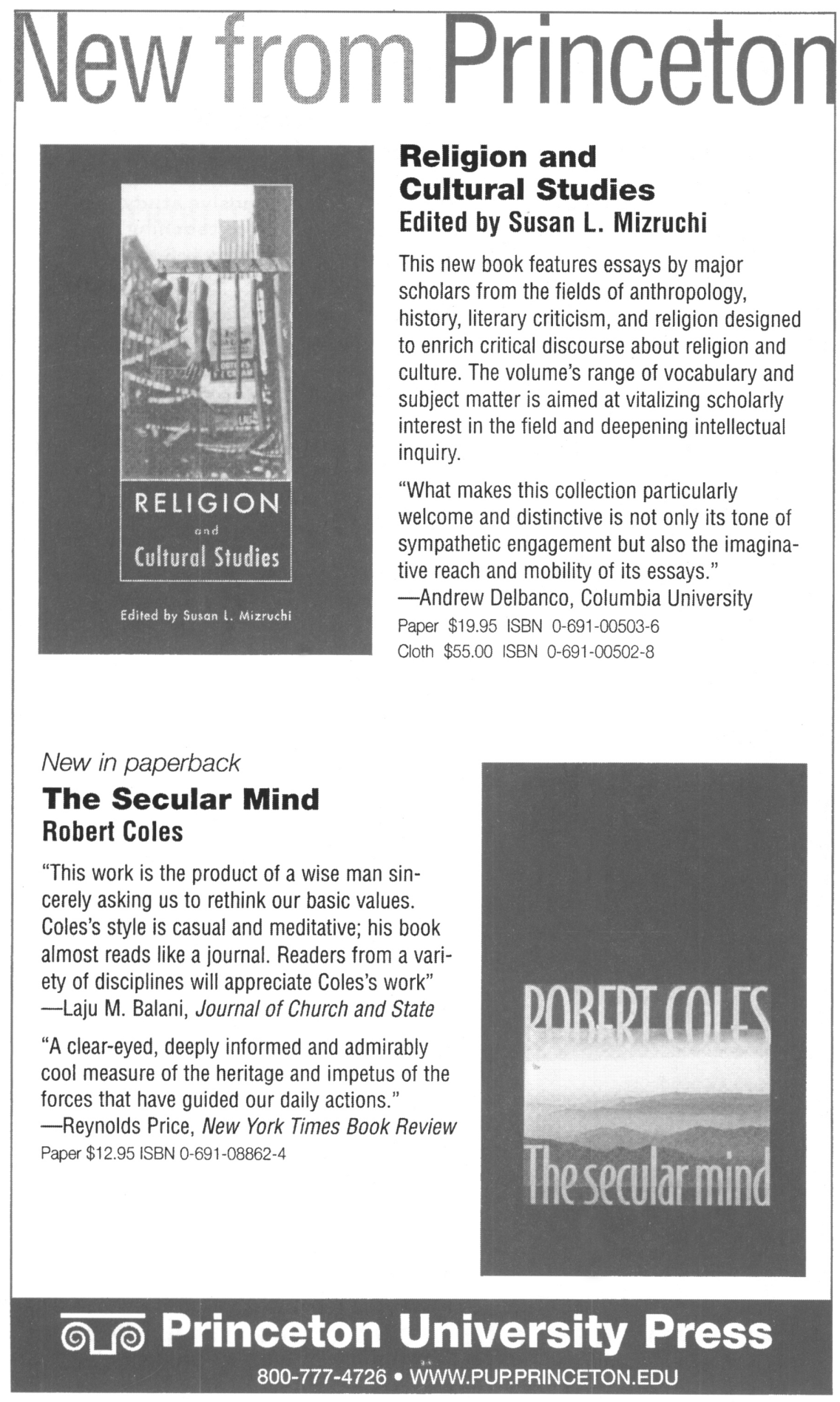




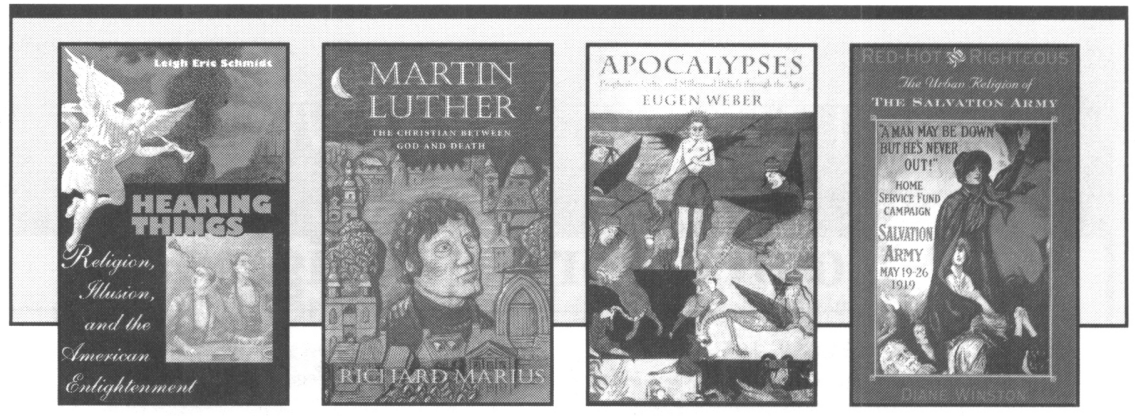

\section{Red-Hot and}

Righteous

The Urban Religion of the Salvation Army

\section{DIANE WINSTON}

"In Red-Hot and Righteous, Winston combines intelligent insights, rich anecdotes and telling facts to chart the remarkable ascent of the Salvation Army, when it landed on US shores, to 1950...

Winston's fine book is a remarkable tale not just of the rise to prominence of the Salvation Army but of the interplay between religion and culture."

-Diego Ribadeneira, Boston Globe $\$ 16.95$ paper

\section{Hearing Things} Religion, Illusion, and the American Enlightenment LEIGH ERIC SCHMIDT

"This densely argued, fascinating [book] features a panorama of colorful characters, from the Swedish mystic Emanuel Swedenborg to the traveling showman William Frederick Pinchbeck and his Pig of Knowledge. Schmidt's study offers an important chapter in the genealogy of the modern religious imagination."

-Publishers Weekly

$\$ 37.50$ cloth

\section{Martin Luther}

\section{The Christian between} God and Death

RICHARD MARIUS

"Richard Marius's fine new biography of Luther resumes that traditional focus of interest in a life first prepared for in 'years of silence' to 1517 (when Luther was thirty-four), and then lived at centre stage in the period down to the 1520s... Marius writes vividly and clarifies complex matters for students." -Michael Mullett, Times Literary Supplement Belknap Press $\bullet \$ 17.95$ paper

\section{Apocalypses}

Prophecies, Cults, and Millennial Beliefs through the Ages EUGEN WEBER

"A noted historian of ideas, [Weber] traces millennial fears and longings in the West from their pre-Christian roots in Persian, Hebrew and Greek Stoic thought right up to Jonestown, Waco and Heaven's Gate. He points out that...there has hardly been a moment when somebody somewhere was not claiming that the end was nigh." -The Economist

$\$ 16.95$ paper 


\title{
Journal of Contemporary Religion
}

\section{EDITOR}

Professor Peter B. Clarke, Centre for New Religions, King's College,

University of London, $U K$

\section{CO-EDITOR}

Dr Elisabeth Arweck, Centre for New Religions, King's College,

University of London, UK

\begin{abstract}
Journal of Contemporary Religion is an international journal concerned with the discussion and analysis of contemporary aspects of religion focusing on significant trends, developments and processes of the past 20-30 years. This includes material on older, more established religions, for example the rise and impact of Islam and the appeal of Japanese Buddhist movements in the United States or Western Europe since 1960. Contributions on current forms of religiosity and spirituality, religious experience in contemporary society, new religions, contemporary fundamentalism, religion and environmental issues are welcome. The Journal also includes review articles dealing with these themes.
\end{abstract}

\section{This journal is also available online.}

Please connect to http://www.tandf.co.uk/online.html for further information.

\section{SUBSCRIPTION RATES}

2000 - Volume 15 (3 issues)

Print ISSN 1353-7903

Online ISSN 1469-9419

Institutional rate: US $\$ 298 ; £ 180$ (includes free online access)

Personal rate: US\$68; $£ 41$ (print only)

\section{ORDER FORM}

PLEASE COMPLETE IN BLOCK CAPITALS AND RETURN TO THE ADDRESS BELOW

Please invoice me at the $\square$ institutional rate $\square$ personal rate

$\square$ Please send me a sample copy

Name

Address

E-mail 


\section{New from California}

\section{Myths in Stone}

Religious Dimensions of

Washington, D.C.

Jeffrey F. Meyer

"Meyer takes his readers on a very different 'tour' of Washington, D.C.

He excavates the ways in which core convictions of a nation are embodied in space and expressed in art and architecture. Myths in Stone is a rich evocation of the dynamic life of America's sacred center."

-Edward T. Linenthal, author of Preserving Memory

$\$ 35.00$ cloth

\section{The Visual Culture of American Religions}

David Morgan \& Sally M. Promey, Editors

"These essays are unusually strong, sophisticated, mature, and insightful. They are remarkably readable, not merely for art historians but also for a broadly interested and intelligent audience. The result is a truly fascinating collection that touches on a wide range of important topics in the two-hundred-year experience of both American art and American religion." -Jon Butler, editor of Religion in American History $\$ 60.00$ cloth, $\$ 29.95$ paper

\section{Creative Spirituality}

The Way of the Artist

\section{Robert Wuthnow}

"A brilliant, insightful exploration of how contemporary artists struggle to express their deepest spiritual yearnings. At a time when the notion of spirituality seems inchoate, artists, writers and musicians can often eloquently articulate the mysterious otherness of our lives."

-Marci Whitney-Schenck, Publisher and Editor, Christianity and the Arts

"A vibrant perspective on spirituality and the meaning of contemporary life."-Publishers Weekly $\$ 27.50$ cloth

\section{Each Mind a Kingdom} American Women, Sexual Purity, and the New Thought

Movement, 1875-1920

Beryl Satter

New in Paperback - "Ambitious, engaging and beautifully written, this study of late-19th-century American women's psychological and intellectual relationship to progressive social movements and quasi-religious selfimprovement cults is a groundbreaking investigation that overturns established paradigms."

-Publishers Weekly 
